\title{
Bankruptcy Prediction Analysis on the Manufacturing Companies Listed in Indonesia Stock Exchange
}

\author{
Henny Setyo Lestari* \\ Faculty of Economics and Business \\ Universitas Trisakti \\ Jakarta, Indonesia \\ *henny_setyo_lestari@trisakti.ac.id
}

\begin{abstract}
This research aims to determine the effect of liquidity, profitability, debt structure, solvency and activity ratio to bankruptcy prediction. The sample used in this research is a manufacturing company that in listed on the Indonesian Stock Exchange (IDX) in the period 2012-2016. The amount of the sample in this research amounted to 88 manufacturing companies, by using purposive sampling. The method of data analysis is done by using logistic regression. The result of this research indicate that profitability and activity ratio have a significant negative effect on bankruptcy, while liquidity, debt structure and solvency have no impact on bankruptcy. The higher a company has a profitability and activity ratio can reduce the risk of bankruptcy and the return on investment obtained by investors will tend to be high.
\end{abstract}

Keywords-activity ratio, bankruptcy, debt structure, liquidity, profitability, solvency

\section{INTRODUCTION}

The bankruptcy is going to cause very large losses. Its effect is to cause the failure of finance, recession, unemployment and the bad economic situation that caused large losses of banks, suppliers, shareholders and the whole community [1]. Bankruptcy Prediction Analysis (CPA) is very important to identify the Organization on financial stability [2]. The bankruptcy of a company usually starts with financial distress that mark by the uncertainty of profitability in the future. Predictions about the company's financial condition, related to the bankruptcy, constitute essential information for stakeholders i.e. creditors, investors, authorities and auditors, rules makers [3].

Analysis on the bankruptcy of a company is very important for the various parties due to the bankruptcy of a company will not only harm the company's parties, but also detrimental to the other parties related to those companies. Bankruptcy prediction analysis can be conducted to gain early warning of bankruptcy or signs of bankruptcy such as profits continued to decline each year, the decrease in the number of production and sales sector each year. Getting the early signs of bankruptcy is known, it will be the better for party management. Management can immediately make improvements-fixes so that the company filed for bankruptcy [4]. In addition, for external companies, such as creditors and shareholders, bankruptcy prediction can be used as a foundation in the financial decision making to cope with the various possibilities that bad is going to happen that is be the downfall of the company in question [5]

There are four approaches related to predict bankruptcy i.e. economic approach, the approach of strategic, managerial and organizational approaches approach to financial [6]. This research focused exclusively on financial approach because this financial approach reflects the symptoms arising from causes of bankruptcy. The approach can also identify financial ratios relevant to the variable $\mathrm{z}$-score, which is generally the variables also gained from reports of profit/loss of companies that include liquidity ratio, profitability ratio, debt structure, solvency and activity ratio which can help to predict bankruptcy within a given time horizon when combined with a variable z-score model [2].

In Indonesia the bankruptcy prediction has been applied because the economy situation is always changing and the number of internal problems that affect the performance and activities of the company [7]. According to the report the economy of Indonesia year 1998 published by Bank Indonesia, there are four fundamental problems that make the economy worse Indonesia in 1998 i.e. macro conditions as well as their impact on the banking sector macroeconomic conditions, the level of complexity and scale of problems facing the state of Indonesia as well as its impact on the implementation of economic policies, socio-political conditions and security as well as its relation to business risks, and global economic conditions [8]. These problems are still the subject of economic problems in Indonesia in recent years.

Can be proven from the number of major companies went bankrupt, recorded during the year 2009 to 2016, Indonesia Stock Exchange (BEI) has been delayed 28 companies 11 of which is a manufacturing company, where previously this manufacturing sector can contribute high enough to advance the country's economy because it can increase the export value of finished goods to other countries. Indonesia's manufacturing industry is currently facing a number of problems. In 2014, the 
manufacturing industry contributes to GDP of $21.45 \%$ and continues to decline to $20.84 \%$ by 2015 .

\section{LITERATURE REVIEW}

Bankruptcy is the company's failure to pay off the debt from its current asset. It can also be said that bankruptcy is described as a failure of legally-stated organizational ability to pay its creditors [9]. There are many differences, including bankruptcy definition get return level significantly and continuously below the level of spending, the company ceased operations or termination for any reason [10]. Bankruptcy means business costs exceed corporate earnings, technical bankruptcy refers to situations where the company has a net worth and a positive profit but has insufficient liquidity to meet current liabilities in paying the operational debt. Bankruptcy is a condition where the company has negative net worth as well as liquidity and in the process of legal reorganization [11].

The techniques used in designing the bankruptcy prediction model can be grouped into three groups of statistical techniques, artificial intelligence techniques, and theoretical models [12]. In this study used theoretical model taken from the measurement proposed by Edward Altman is a $\mathrm{Z}$-score model. This Z-score has three kinds of discriminant functions used to calculate three types of companies: the original z-score 1968 to calculate the manufacturing company going public, Altman z-score 1983 for private or closed manufacturing and then Altman z-score 1995 used to predict the bankruptcy of non-manufacturing companies. In this study, used calculations for manufacturing companies that go public, where the ratio of working capital to total assets, retained earnings with total assets, EBIT ratio with total assets, book value of equity ratio with book value of total debt, and sales ratio with total assets [2].

Liquidity or liquidity is a ratio that indicates a company's ability to meet its obligations or pay its short-term debt. This ratio can be used to measure how a company is likuid. If the company is able to fulfill its obligations it means the company is liquid, whereas if the company is unable to fulfill its obligations the company is likuid [13]. Liquidity measures the company's ability to pay its current obligations (payable in one year) with current assets such as cash, accounts receivable and inventories [14]. In this study using current ratio in measuring liquidity is current assets divided by current liabilities [2]. The greater the liquidity ratio, the less likely the company will experience bankruptcy. The company's current assets are high, then the company's ability to pay its debts will get better. High Liquidity, will increase the availability of current assets in a company in the form of cash, so it can continue to meet its short-term obligations and avoid the risk of bankruptcy.

Profitability consists of two words that is, profit and ability. The term profit is the amount of money obtained from the sale proceeds in a certain period. The term ability shows the strength of a business entity to acquire something. Profitability can be defined as the ability of a company to make a profit through all available resource capabilities such as sales activities, cash, capital, number of employees, number of branches, etc. [15]. In this study the measurement for profitability uses the ROA ratio using the earnings before interest and tax formula divided by total assets because it measures how efficiently a company generates earnings before interest and taxes are paid. These measurements allow more accurate comparisons of the company due to the neglect of various tax situations and levels of financial leverage so as to provide an idea of how good a company uses its assets to generate revenue [2]. Profitability shows the efficiency and effectiveness of the use of company assets because this ratio measures the ability of a company generating profits based on the use of the asset. Adequacy of funds generated from such profits will reduce the risk of corporate bankruptcy [2].

Debt structure or the structure of the debt is one of the external funding structures used by the company to fund the activities of the company. Structure that indicates the relative proportions of total debt used to finance the company's assets. Debt structure measures the proportion of total liabilities are paid in the current year or in the next accounting period divided by the total assets of the company [6]. In this study to measure the debt structure ratio, using the ratio of total liabilities divided by total assets because it measures the proportion of debt used to finance the company's assets [16]. High debt structure will increase the company's capital so it can give an indication of the ability to repay the total debt previously and can return the capital and generate new profit that can lower the probability of bankruptcy [16].

Solvency refers to a company's ability to fulfill its obligations in the long term. This means the ability of the company to pay its obligations in the long term, including interest and principal debt. In other words, this represents the company's financial structure [4]. Solvency provides an overview of debt in the company's capital structure, as well as the ability of cash to cover interest costs and fixed costs such as rent payments [17]. In this study to measure solvency ratio the unambiguous measurement used by Cultrera, Croquet, and Jospin [2], that's cash flow divided by total debt due to measure how large the proportion of the company's ability to pay its debts with a current total annual cash. There is a company that has a high cash flow will avoid the risk of bankruptcy because of the flow of cash from higher cash out, meaning the resulting income greater than expenses. Incoming cash flow contributed to the debt payments are usually based on the liquidation of assets and also the return on assets.

Activity ratio is a financial ratio that measures how the company effectively manages its assets. This ratio is used by companies to see how much the level of assets owned by the company, whether it is appropriate and reasonable, very high or very low if viewed from the current level of sales. The higher the activity ratio, the more effective the company uses its resources [18]. In this study the measurement for the activity ratio using the ratio of total asset turnover is sales divided by total assets of the company. According to research Odibi, Basit, and Hassan [19] total asset turnover is the best measurement to be a benchmark company in assessing whether or not the 
company's health is measured through the level of sales volume. Activity ratio measures how big the company's sales volume, if the sales volume increases, it will continue to increase the company's profit so it can avoid the risk of bankruptcy. Thus, activity ratios have a negative influence on bankruptcy [20].

\section{METHODS}

This research aims to analyze the effect of the independent variable that consists of liquidity, profitability, solvency, debt structure and activity ratio dependent variable towards bankruptcy. To be able to obtain the sample in this study then the sampling method used is the method of purposive sampling which is the selection of the samples are not random that the information obtained using specific criteria tailored to goals and the formulation of research problem. The criteria are as follows manufacturing companies listed on the Indonesia Stock Exchange in 2012-2016, the company publishes a complete financial report for the year 2012-2016 and the currency used of the company in the form of Indonesian rupiah (IDR).

Dependen variable used in this research is bankruptcy, where this research will predict bankruptcy or bankruptcy at manufacturing company, it can be measured by using dummy variable where there are 2 samples, that is, company which is not given is given value 0 and the company that experienced bankruptcy is given value 1 . Before giving such values, performed measurements with model Altman's Z-Score to know those companies into bankruptcy or not. The measurement of these variables is on table 1 as follows:

TABLE I. VARIABLES AND MEASUREMENTS

\begin{tabular}{|c|c|c|c|}
\hline Variables & Measurements & $\begin{array}{l}\text { Expected } \\
\text { Sign }\end{array}$ & Literature \\
\hline \multicolumn{4}{|l|}{$\begin{array}{l}\text { Independent } \\
\text { Variables }\end{array}$} \\
\hline Liquidity & $\begin{array}{lrl}\text { Current Assets } \\
\text { Current Liabilities }\end{array}$ & $(-)$ & [6] \\
\hline Profitability & EBIT / Total Assets & $(-)$ & [6] \\
\hline Debt Structure & $\begin{array}{l}\text { Total Liabilities / Total } \\
\text { Assets }\end{array}$ & $(-)$ & [16] \\
\hline Solvency & Cash Flow / Total Debt & $(-)$ & [6] \\
\hline Activity & Sales / Total assets & $(-)$ & [19] \\
\hline \multicolumn{4}{|l|}{$\begin{array}{l}\text { Dependent } \\
\text { variables }\end{array}$} \\
\hline Bankcruptcy & $\begin{array}{l}\text { Model Altman's Z- } \\
\text { Score } \\
Z=0.012 X_{1}+0.014 \\
\text { X2 + } 0.033 \text { X3 + } \\
0.006 \mathrm{X} 4+0.999 \mathrm{X} 5\end{array}$ & & \\
\hline
\end{tabular}

Data analysis method used in this research is logistic regression model or logistic regression model. Logistic regression analysis aims to examine and analyze the influence of independent variables namely, liquidity, profitability, debt structure, solvency and activity ratio to the dependent variable that is bankruptcy in manufacturing companies listed in Indonesia Stock Exchange (IDX). The logistic regression model in this study is as follows:
Bankruptcy $=\alpha+\beta_{1} \mathrm{LR}_{\mathrm{it}}+\beta_{2} \mathrm{PR}_{\mathrm{it}}+\beta_{3} \mathrm{DSR}_{\mathrm{it}}+\beta_{4} \mathrm{SVR}_{\mathrm{it}}+$ $\beta_{5} \mathrm{ATR}+\varepsilon$

\section{RESULTS AND DISCUSSION}

Descriptive statistics aims to provide an overview and description of the data by using the statistics approach. Descriptive statistics describes the characteristics of the data used in the study who seen from the minimum, maximum, average and standard deviation. The minimum value is the lowest value of each variable, the maximum value is the highest value of each variable, the mean is the average value of each variable, and the standard deviation indicates the distribution of data used in the study reflecting the heterogeneous or homogeneous data that has fluctuating.

TABLE II.

DESCRIPTIVE STATISTICS

\begin{tabular}{|l|l|l|l|l|c|}
\hline \multicolumn{1}{|c|}{ Variables } & Obs. & \multicolumn{1}{c|}{ Mean } & Maximum & Minimum & Std. Dev \\
\hline Bankcruptcy & 440 & 0.900000 & 1 & 0 & 0.3030000 \\
\hline Liquidity & 440 & 4.022937 & 464.9844 & 0.1238 & $\begin{array}{l}25.030992 \\
6\end{array}$ \\
\hline Profitability & 440 & 0.099835 & 0.8557 & -0.5918 & 0.1257973 \\
\hline $\begin{array}{l}\text { Debt } \\
\text { Structure }\end{array}$ & 440 & 0.506365 & 3.0291 & 0.0372 & 0.3962642 \\
\hline Sovency & 440 & 0.166352 & 9.6097 & -5.1242 & 0.7821506 \\
\hline Activity & 440 & 1.083307 & 4.3402 & 0.0150 & 0.5549323 \\
\hline
\end{tabular}

Based on the descriptive statistical results in table 2 can be seen as a whole the research sample consisting of 88 manufacturing companies listed on the Indonesia Stock Exchange for 5 years found $n=440$. One independent variable, namely liquidity, has an average of 4.022937 with a standard deviation of 25.0309926. The maximum value is 464.9844 and the minimum value is 0.1238 .

TABLE III. T-TEST RESUlT (HYPOTHESIS TEST)

\begin{tabular}{|l|l|l|}
\hline \multicolumn{1}{|c|}{ Variables } & \multicolumn{1}{|c|}{ Coefficient } & \multicolumn{1}{c|}{ Prob. } \\
\hline Liquidity & -0.015 & 0.778 \\
& & $(0.053)$ \\
\hline Profitability & -12.553 & $0.016 *$ \\
& & $(5.202)$ \\
\hline Debt Structure & -1.697 & 0.614 \\
& & $(3.361)$ \\
\hline Solvency & 1.990 & 0.256 \\
& & $(1.752)$ \\
\hline Activity & -22.253 & $0.002 *$ \\
& & $(7.186)$ \\
\hline \multicolumn{2}{|c|}{ *Significance level of 0.05 , respectively. Standard errors are in brackets. } \\
\end{tabular}

Based on the analysis results, this shows there is no influence between liquidity against bankruptcy. The results of this study are not in line with research conducted by Cultea et al. [2] who found that liquidity has a negative effect on bankruptcy. But the results of this study in accordance with the research conducted by Low, Nor and Yatim [21] and Charalambakis [22], they found no effect on liquidity for bankruptcy. High low liquidity of the company, unable to predict the bankruptcy on the company because in predicting 
bankruptcy not only viewed from a short-term obligation however to be seen also long-term liabilities.

The results of this study are in line with the results of research Cultera et al. [2] who found that the profitability ratio has a negative effect on bankruptcy. This ratio measures the amount of profit generated by the company, the higher the profit then the company will increasingly avoid the risk of bankruptcy. Companies with a high level of profitability indicate the company is able to generate profits, which can be used for various things both to fund the activities of the company and pay its obligations. Thus, the company can avoid the risk of bankruptcy.

Based on the results of the analysis, this shows that there is no influence between debt structure to bankruptcy. The results of this study are not in line with research conducted by [2] who found that the debt structure has a negative effect on bankruptcy. But the results of this research are reinforced by research conducted by Nyamboga et al. [23] and Liana and Sutrisno [24], they find the debt structure has no effect against bankruptcy. These results indicate that high low debt structure of a company does not affect the probability of the bankruptcy in a company. The insignificant effect between debt structure and bankruptcy occurs because even though the company has a lot of debts for its operational financing, factors such as assets owned and profit generated are able to overcome it so that the company will avoid the risk of bankruptcy.

Based on the analysis results, this shows that there is no influence between solvency to bankruptcy. The results of this study are not in line with research conducted by Cultera et al. [2] who found that the solvency ratio had a negative effect on bankruptcy. But the results of this study are in accordance with the results of research by Cultera and Bredart [6] and Islam, Semeen, and Farah [25], they found solvency has no effect on bankruptcy. These results indicate that the high or low solvency ratio of a company does not affect the risk of bankruptcy in a company. Although basically high cash flow can reduce the risk of bankruptcy, but with a certain proportion of cash flow cannot describe that the company is able to pay the total debt to creditors so that the solvency ratio of a company does not affect the risk of bankruptcy in a company.

The results of this study are in line with the results of the study of Odibi et al. [19] who found that activity ratios negatively affect bankruptcy. Activity ratio is a ratio that measures how much the volume of sales in a company which means if this ratio increases then the volume of sales in a company will continue to increase and if the volume of sales increases, would result in higher profits that can reduce the risk of bankruptcy in a company.

\section{CONCLUSION}

Based on the results of analysis and discussion it can be drawn conclusion as follows: profitability and activity ratio proved statistically significant effect on bankruptcy. The result shows that profitability has a negative effect on bankruptcy while activity ratio also negatively affect bankruptcy. While the liquidity, debt structure and solvency are not statistically significant effect on bankruptcy. The higher a company has a profitability and activity ratio can reduce the risk of bankruptcy and the return on investment obtained by investors will tend to be high. Adding independent variables to perfect research such as stock prices [26].

\section{REFERENCES}

[1] C. Sungbin, H. Hong, and H. Byoung-Chun, "A hybrid approach based on the combination of variable selection using decision trees and casebased reasoning using the Mahalanobis distance: for bankruptcy prediction," Expert Syst. Appl., vol. 37, no. 4, pp. 3482-3488, 2010.

[2] L. Cultrera, M. Croquet, and J. Jospin, "Predicting bankruptcy of Belgian SMEs: A hybrid approach based on factorial analysis," Int. Res. J. Financ. Econ., vol. 10, no. 3, pp. 33-41, 2017.

[3] M. Wang and H. Shiu, "Research on the common characteristics of firms in financial distress into bankruptcy or recovery," Invest. Manag. Financ. Innov., vol. 11, no. 4, pp. 233-243, 2014.

[4] X. Bredart, "Bankruptcy Prediction Model: The Case of the United States,” Int. J. Econ. Financ., vol. 6, no. 3, pp. 1-7, 2014

[5] O.A. Jawabreh, F. Al-rawashdeh, and O. Senjelawi, "Using Altman's ZScore model to predict the financial failure of hospitality companiescase of Jordan,” Int. J. Information, Bus. Manag., vol. 9, no. 2, pp. 141$157,2017$.

[6] L. Cultrera and X. Bredart, "Bankruptcy Prediction: The case of Belgian SMEs,” Rev. Account. Financ., vol. 15, no. 1, pp. 101-119, 2016.

[7] Y. Peter, "Bankruptcy analysis with method of Z-Score Altman, Springate, and Zmijewski at PT Indofood Sukses Makmur Tbk. for the Period of 2005-2009," Accurate J. Sci. Account., vol. 2, no. 4, 2011.

[8] R. Rantelino, "Prediksi kebangkrutan perusahaan properti yang terdaftar di Bursa Efek Indonesia Tahun 1998-2013,” J. Manaj. Keuangan, Fak. Ekon. Univ. Kristen Petra, vol. 3, no. 1, pp. 96-101, 2015.

[9] A.R. Sandin and M. Porporato, "Corporate bankruptcy prediction models applied to emerging economies: Evidence from Argentina in the years 1991-1998," Int. J. Commer. Manag., vol. 17, no. 4, pp. 295-311, 2008.

[10] J. Samuel Baixauli and A. Módica-Milo, "The bias of unhealthy SMEs in bankruptcy prediction models," J. Small Bus. Enterp. Dev., vol. 17 no. 1, pp. 60-77, 2010.

[11] S. Fathi, A. Shahin, B. Akbari, and M. Safanoor, "Meta Analysis of the Impact of Factors Related to Research Structure on the Strength of Bankruptcy Prediction Models and Variables," J. Basic Appl. Sci. Res. vol. 1, no. 2, pp. 10092-10102, 2012.

[12] I.J. Azis, "Predicting a recovery date from the economic crisis of 2008," Socio-Economic Plan. Serv., vol. 44, pp. 122-129, 2008

[13] P. Proenca, R.M.S. Laureano, and L.M. Laureano, "Determinants of capital structure and the 2008 financial crisis: evidence from Portuguese SMEs,” Int. Strateg. Manag. Conf., vol. 10, pp. 182-191, 2014.

[14] P. Ohman and D. Yazdanfar, "Short-and long-term debt determinants in Swedish SMEs," Rev. Account. Financ., vol. 16, no. 1, pp. 106-124, 2016.

[15] M. Tulsian, "Profitability analysis (a comparative study of SAIL and TATA steel," IOSR J. Econ. Financ., vol. 3, no. 2, pp. 19-22, 2014.

[16] E.L. von Thadden, E. Berglöf, and G. Roland, "The design of corporate debt structure and bankruptcy," Rev. Financ. Stud., vol. 23, no. 7, pp. 2648-2679, 2010.

[17] O.T. San and T.B. Heng, "Capital structure and corporate performance of Malaysian Construction sector,” Int. J. Humanit. Soc. Sci., vol. 1, no. 2, pp. 28-36, 2011. 
[18] H. Muhammad, Z. Shah, B., Islam, M. Waqas, and D. Khan, "Comparative evaluation of financial performance of Pakistan Tobacco Company (PTC) and Philip Morris Pakistan Limited (PMPKL) through ratio analysis," Int. Kournal Manag. Sci. Bus. Res., vol. 3, no. 1, 2013.

[19] I. Odibi, A. Basit, and Z. Hassan, "Bankruptcy Prediction Using Altman Z-Score Model: A Case of Public Listed Manufacturing Companies in Malaysia," Int. J. Account. Bus. Manag., vol. 3, no. 2, pp. 178-186, 2015.

[20] M.H. Tinoco and N. Wilson, "Financial distress and bankruptcy prediction among listed companies using accounting, market and macroeconomic variables," Int. Rev. Financ. Anal., vol. 30, pp. 394 419, 2013.

[21] S.W. Low, F.M. Nor, and P. Yatim, “'Predicting corporate financial distress using the logit model: The case of Malaysia," vol. 6, no. 1, pp. $49-61,2001$.
[22] E.C. Charalambakis, "On the prediction of corporate financial distress in the light of the financial crisis: empirical evidence from Greek listed firms," Int. J. Econ. Bus., vol. 22, no. 3, pp. 407-428, 2015.

[23] T.O. Nyamboga, B. N. Omwario, A. M. Muriuki, and G. Gongera, "Determinants of corporate financial distress: case of non-financial firms listed in Nairobi Securities Exchange,” Res. J. Financ. Account., vol. 5, no. 12, pp. 193-207, 2014.

[24] D. Liana and Sutrisno, "Analisis rasio keuangan untuk memprediksi kondisi financial distress pada perusahaan manufaktur," J. Stud. Manaj. dan Bisnis, vol. 1, no. 2, 2014.

[25] M.S. Islam, H. Semeen, and N. Farah, "The effects of financial ratios on bankruptcy," Indep. Bus. Rev., vol. 6, no. 2, pp. 52-67, 2013.

[26] B.A. Nouri and M. Soltani, "Determinants of foreign direct investment in Cyprus," J. Adv. Res. Law Econ., vol. 7, no. 2, p. 341, 2016. 